\title{
Editorial- Journal of Clinical Infectious Diseases: Open Access (ISSN: 2684 - 4559)
}

\section{Balakumaran Manickam Dakshinamoorthi* \\ Department of Biotechnology, Chennai, India}

Hilaris: Clinical Infectious Diseases: Open Access Journal has been started in the year 2017and it released its first volume in the same year. Till now, the journal has released 3 volumes before the finish of 2019 and is effectively running its fourth Volume.

Journal of Clinical Infectious Diseases: Open Access has emerged as an important discipline of science which is multidisciplinary in nature. Different subjects such as various Pathogens, including Invasive Candidacies, Aspergillosis, Norovirus and mycobacteria that may infect the human beings causing health disorders like Invasive Fungal Disease, Extensive Disease, Systemic Illness, Cytomegalovirus (Cmv) Infection, Recurrent Infection, Surgical Wound Infection, Clinical Microbiology, Invasive Fungal Disease, Flu, Communicable Diseases and Clostridium Difficile Infection. The journal also focuses extensively on the Fungal Etiology, Enterobacteriaceae, Epidemiology, Neutropenia, and Probiotics and related content fields are involved to develop this subject as a unique discipline.

Journal of Clinical Infectious Diseases: Open Access is the best open access journal that aims to publish most complete and reliable source of information on the discoveries and advanced developments in this field in the form of original articles, review articles and short communications etc. and provide free online access to it with no limitations or some other memberships to scientists around the world. This peer reviewed journal is capably upheld by generally conspicuous Editorial Board members.

The Journal of Clinical Infectious Diseases: Open Access peer reviewed Journal is proficiently supported by universally prominent Editorial Board members. JID undergo a single blind peer review process by competent Editorial Board so as to ensure excellence.

\section{Classification of the Journal}

- $\quad$ Babesiosis

- Clostridium Difficile Infection

- $\quad$ Cross Infection

- $\quad$ Flu-Like Illness

- $\quad$ Fungal sinusitis

- Gastroenteritis

- $\quad$ Gingivitis

The classification extends to the above mentioned and its related subjects as well.

During the year 2018, the Journal has released nearly 18 articles.

*Address for Correspondence: Balakumaran Manickam Dakshinamoorthi, Department of Biotechnology, Chennai, India, E-mail: dakshinbala@gmail.com

Copyright: (c) 2020 Dakshinamoorthi BM. This is an open-access article distributed under the terms of the Creative Commons Attribution License, which permits unrestricted use, distribution, and reproduction in any medium, provided the original author and source are credited.

Received 10 September 2019; Accepted 15 September 2020; Published 22 September 2020
Some of the articles released in 2019 are as per the following:

1. Autolysin-Independent DNA Release in Streptococcus pneumoniae In vitro Biofilms

2. An Outbreak of Typhus Fever from Western India

3. Impact of Loop Residues of the Receptor Binding Domain of Bacillus thuringiensis Cry2ac11 Toxin on Insecticidal Activity

4. Leprosy: A Time for Elimination by 2020

5. Viral and Bacterial Coinfection in Patients with Neurological Disorders: An Analytical Cross-Sectional Study from Karachi

6. Evaluation of Immune Response to Hepatitis B Vaccine in Laboratory Workers, Khartoum, Sudan

7. Quality Control Issues in Antibiotic Susceptibility Testing by Disc Diffusion Technique

8. Evaluation of Bactericidal Activity of Monoclonal Antibodies Obtained from Neisseria meningitidis

9. Probiotic Related Lactobacillus rhamnosus Endocarditis in a Patient with Liver Cirrhosis and Literature Review

10. Deadly Attack against Trypanosoma cruzi

Similarly, the Journal hopes to cover all the above classification topics for the year 2020 alongside the current examination in this field alongside the current situation prevailing in all around the world i.e., COVID19.

\section{Social media/digital marketing}

The journal consistently was in contact with the scientific group of the world through its mails, social media systems and its advanced stages. The absolute most ideal approaches to be in contact with the crowds are:

Twitter postings: Regularly posting the articles, patterns, updates of the journal. They can be visible at: https://twitter.com/clininfectidis.

Posting Google Analytics data in the website.

Using Linkedln and Facebook for regular updates.

Consistently being in contact through mails as well as through Whats App.

The complete details about the journal can be seen at: Clinical Infectious Diseases: Open Access

Lastly, Clinical Infectious Diseases: Open Access Journal is nothing without the continuous support of the Editorial Board Members especially our Editorial Board members are the back bone of the journal.

Alongside them, authors and reviewers assume a huge role in building this journal. Thus, as an Editorial Co-ordinator I welcome all the allencompassing dignitaries in this field to present their articles for bringing this exploration/ability to the worldwide scientific community.

\section{Editors}

\section{Alberto Corona}

Professor 
University of Milano, Italy

\section{Emmanuel Andres}

Professor

Department of Internal Medicine,

University of Strasbourg, France

\section{Reviewers}

Christian Sandrock
Divisionof Infectious Disease

University of California, Davis School of Medicine, USA

How to cite this article: Balakumaran Manickam Dakshinamoorthi. "EditorialJournal of Clinical Infectious Diseases: Open Access (ISSN: 2684 - 4559)".

Clin Infect Dis 4 (2020) doi: 10.37421/jid.2020.4.126 